\section{Similarity in the Molecular Shapes of the Alcohol Moieties of Pyrethroids}

\section{Toshiyuki Katagi and Yasuyuki Kurita*

\author{
Laboratory of Biochemistry and Toxicology \\ * Pesticides Research Laboratory, \\ Takarazuka Research Center, \\ Sumitomo Chemical Co., Ltd., \\ Takatsukasa, Takarazuka 665, Japan
}

(Received September 21, 1988)

\section{INTRODUCTION}

Pyrethroids possessing various acid and alcohol moieties have been synthesized with the chemical structure and metabolic fate of natural pyrethrins in mind. Although the mode of action of pyrethroids has not been fully clarified, it is considered that their high insecticidal activity depends primarily on the overall shape of the molecule, and that other properties such as electron density and polarizability are of secondary importance. ${ }^{1)}$ With stereochemical interest, the lower energy conformations of some pyrethroids have been theoretically studied., ${ }^{2,3}$ A geometric study on chrysanthemic and 3-methyl2-phenylbutyric acids has revealed that these two acid moieties of pyrethroids can be superimposed on each other with the dimethyl and the unsaturated groups at remarkably similar positions. ${ }^{4)}$ With respect to the alcohol moiety, Elliott ${ }^{5)}$ has qualitatively discussed molecular similarity, and Nishimura et al. ${ }^{6)}$ have reported that steric bulkiness is important for the higher activity of substituted benzyl chrysanthemates. However, the steric parameters common to alcohol moieties of potent pyrethroids have not been quantitatively discussed yet. Pyrethroids are divided into types I and II, which are different in neuro-physiological action ${ }^{7)}$ and seem to act at distinct sites on the nervous system, ${ }^{8)}$ and they should be separately studied on steric parameters.

Based on the above considerations, this report deals with the lower energy conformations of alcohol moieties of pyrethrin-I and the other type I pyrethroids (excluding a cyano group) investigated by PCILO (Perturbative Configuration Interactions using Localized Orbitals) and AM1 (Austin Model 1) calculations. Similarities in molecular shape and electronic property among these alcohol moieties are discussed with the computer graphics system ACACS $^{9}$ loaded on an NEC ACOS system 430.

\section{CALCULATIONS}

\section{Conformational Analysis}

The acetate of each alcohol, as shown in Fig. 1,<smiles>C=CCCCC1=C(C)C(OC(C)C)CC1=O</smiles><smiles>C#CCC1=C(C)C(OC(C)=O)CC1=O</smiles>

(IV)<smiles>CCCc1ccc(COC(C)=O)o1</smiles>

(V)

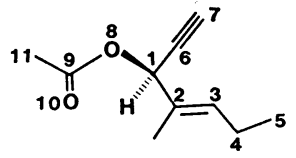

(VI)<smiles>CC(=O)OCc1cccc(Oc2ccccc2)c1</smiles>

(VII)

Fig. 1 Chemical structures and atomic notations of the acetate of the alcohol moiety of (I) pyrethrin-I, (II) bioallethrin, (III) bioresmethrin, (IV) prallethrin, (V) furamethrin, (VI) empenthrin and (VII) phenothrin.

“*” indicates the midpoint of the unsaturated bond used to estimate the ' $d$ ' value. 
was subjected to molecular calculations. The initial geometry was generated from the standard bond lengths and bond angles by using ACACS. The initial dihedral angles were chosen so that the staggered conformations could be realized. The $[S]$ configuration was assumed at $\mathrm{C}_{2}$ for (I), (II) and (IV), and at $\mathrm{C}_{1}$ for (VI). The initial geometry was fully optimized by using the AMPAC program with AM1 parametrization. ${ }^{10)}$ In order to find the global and local minimum energy conformations, the conformational energy was further studied by PCILO calculations at the CNDO level. ${ }^{11)}$ The conformation was changed stepwise by rotating $15^{\circ}$ around each bond, and the bond polarity was optimized at each rotation. The relative energy $(\Delta E)$ to the global minimum was calculated from the total energy in the 3rd perturbation and plotted versus each rotation around the bond axis. The curve fitting with a spline method and the preparation of a contour map were carried out with a Microresearcher ${ }^{\text {TM }}$ loaded on an NEC PC-9801 computer. The molecular geometry of the lower energy conformer obtained by PCILO was finally refined by $\mathrm{AM} 1$.

\section{Steric Parameters}

Since several internal rotations would determine the overall molecular shape, the following steric parameters were introduced to this study. Three planes were defined as shown in Fig. 2. Each of them represents the plane of each molecular fragment corresponding to the acyl moiety, cyclopentenone ring or $\mathrm{C}=\mathrm{C}$ double bond at the 2-position of the 2,4-pentadienyl moiety of $(\mathbf{I})$. Dihedral angles $\theta_{1}$ and $\theta_{2}$ were defined by planes (a) and (b), and (b) and (c), respectively. The distance between the carbonyl

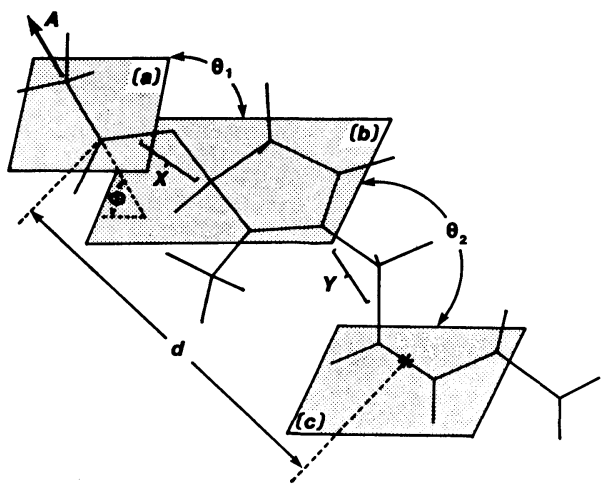

Fig. 2 Definition of steric parameters.

$\mathrm{X}$ and $\mathrm{Y}$ represent a spacer atom or moiety. The skeleton of $(\mathbf{I})$ is an example. carbon atom of the acyl moiety and the midpoint (indicated as an asterisk in Figs. 1 and 2) of the unsaturated bond in the side chain of the alcohol moiety, which is defined as 'd', was calculated in order to examine whether the optimal distance for an activity exists. The direction of the acyl methyl group, which corresponded to an acid moiety of pyrethroid and might determine the overall molecular shape, was also studied by direction vector $\mathrm{A}$ and angle $\phi$. Angle $\phi$ was defined by $\mathrm{A}$ and plane (b). These steric parameters were calculated, based on the Cartesian coordinates of all atoms in each global minimum conformation obtained by AM1 calculations.

\section{Similarity in Molecular Shape}

The structure-activity relationship on the alcohol moiety of synthetic pyrethroid has shown that the planar structure corresponding to the cyclopentenone ring of $(\mathbf{I})$ is required for a higher activity. ${ }^{1)}$ In addition, the $\mathrm{C}=\mathrm{C}$ double bond at the 2-position of the 2,4-pentadienyl group of (I) is often requisite for an activity, while that at the 4-position is not of any significance. ${ }^{5)}$ The global minimum energy conformer of each alcohol moiety was superimposed on that of (I) (conformer 1), therefore, under the condition that the moieties in planes (b) and (c) were matched between the compared molecules. Superimposition was conducted by minimizing the RMS (root mean square) deviation of distances between the selected atoms in each molecule by using ACACS. ${ }^{12,13)}$ The molecular similarity was evaluated by the RMS values. Eight to fourteen atoms were selected to compare two molecules.

\section{Electronic Properties}

Although the size and shape of a molecule are considered important for molecular recognition at a pyrethroid receptor, electronic properties such as distributions of frontier molecular orbitals and electrostatic potential may affect the binding with the receptor. Therefore, the results of AM1 calculations obtained for the global minimum conformer of each alcohol moiety were applied to examine the importance of the electronic properties. The electrostatic potential was calculated by point charge approximation, and displayed on the molecular surface defined by the van der Waals radius of each atom. The electrostatic correlation between the compared molecules (ESC) was also calculated by the method reported by Nakayama \& Richards, ${ }^{14)}$ and the electrostatic potentials were compared on the molecular surface of (I) by the method of 
Kurita \& Takayama. ${ }^{15)}$ Index ESC takes values in the range of -1 to 1 with $\mathrm{ESC}=1$, indicating the similarity in electrostatic potential between the compared molecules.

\section{RESULTS AND DISCUSSION}

\section{Global Minimum Conformations}

The results of conformational analysis of (I) (conformer 1) by PCILO are shown in Fig. 3. The internal rotations $\phi_{1}-\phi_{5}$ are defined as listed in Table 1. The steric hindrance between the acyl and cyclopentenone moieties results in enormous rotational barriers at $\phi_{1}=0-90^{\circ}$ and $270-360^{\circ}$ (Fig. 3-(a)) and $\phi_{2}=90-150^{\circ}$ and 300 $360^{\circ}$ (Fig. 3-(b)). The contour map of $\triangle E$ vs. $\left(\phi_{3}, \phi_{4}\right)$ (Fig. 3-(c)) shows that the four lower energy conformations could exist. The rotation around $\phi_{5}$ is almost free since the energy barrier is ca. $6 \mathrm{kcal} / \mathrm{mol}$ at $\phi_{5}=0^{\circ}$ (Fig. 3-(d)). The conjugation of $\pi$-electrons in the 2,4-pentadienyl moiety seems to reduce the total energy, as evidenced by PCILO and AM1 calculations. Many possible conformers in a lower energy state were predicted based on the conformational analysis by PCILO, but the geometry optimization of these conformers by AM1 with $\phi_{5}$ fixed

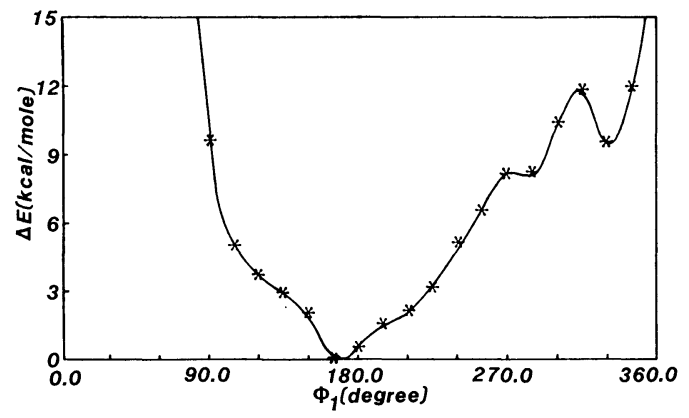

(a)



(c) at $180^{\circ}$ showed that only four conformers could exist at the end in a lower energy state. This may be due to the simpler parametrization of PCILO at the CNDO level as compared with AM1. The refined molecular geometry and electronic properties of each lower energy conformer are summarized in Table 1. Supposing that (I) mainly exists in these four conformations, population $(P)$ of each conformer at $298 \mathrm{~K}$ can be calculated from their total energy by using the Boltzmann partition function. $P$ values listed in Table 1 indicate that $(\mathbf{I})$ prefers conformers 1 and $2(P=98.9 \%$ in total). Since the population of conformer 1 is higher than that of conformer 2, and only $\phi_{3}$ is different between them, conformer 1 is conveniently assumed to be an active conformer of (I).

The global minimum conformations of other alcohol moieties were similarly estimated as above. (II) and (IV) were similar in configuration to (I), as speculated by their structural similarity. The conformational analysis around the two adjacent bonds connecting two aromatic rings showed that (III) (Fig. 4) and (VII) possessed the six and four lower energy states, respectively, which could switch from one to another with a



( b )

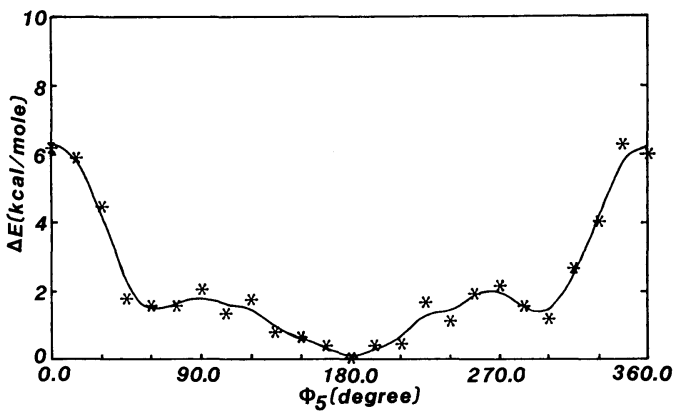

(d)

Fig. 3 Conformational analysis of (I) at (a); $\phi_{1},(\mathrm{~b}) ; \phi_{2},(\mathrm{c}) ;\left(\phi_{3}, \phi_{4}\right)$ and (d); $\phi_{5}$.

"L" indicates a lower energy state. 
Table 1 Molecular geometries of lower energy conformers of (I) estimated by PCILO and AM1 calculations.

\begin{tabular}{lcrrr}
\hline & \multicolumn{4}{c}{ Lower energy conformer } \\
\cline { 2 - 4 } & 1 & 2 & 3 & 4 \\
\hline$\phi_{1}$ & -178.6 & -178.3 & -178.6 & -178.0 \\
$\phi_{2}$ & -98.7 & -100.1 & 63.5 & 65.0 \\
$\phi_{3}$ & -129.0 & 62.0 & -130.5 & 66.1 \\
$\phi_{4}$ & 175.4 & 143.5 & 179.5 & -178.0 \\
$\phi_{5}$ & 178.0 & -179.3 & -81.75 & -81.29 \\
$H$ & -84.35 & -84.19 & 4.528 & 4.675 \\
$D$ & 2.973 & 2.865 & -9.073 & -8.995 \\
$E($ HOMO) & -9.109 & -9.088 & -0.162 & -0.176 \\
$P($ LUMO) & -0.258 & -0.272 & 0.780 & 0.320
\end{tabular}

$\phi_{1}-\phi_{5}$ : Dihedral angle (degrees), $\phi_{1}: \mathrm{C}_{2}-\mathrm{O}_{12}-\mathrm{C}_{13}-\mathrm{C}_{15}, \phi_{2}: \mathrm{C}_{1}-\mathrm{C}_{2}-\mathrm{O}_{12}-\mathrm{C}_{13}, \phi_{3}: \mathrm{C}_{4}-\mathrm{C}_{5}-\mathrm{C}_{7}-\mathrm{C}_{8}, \phi_{4}: \mathrm{C}_{5}-\mathrm{C}_{7}-$ $\mathrm{C}_{8}-\mathrm{C}_{9}$, and $\phi_{5}: \mathrm{C}_{8}-\mathrm{C}_{9}-\mathrm{C}_{10}-\mathrm{C}_{11}$.

$H$ : Heat of formation (kcal/mol), $D$ : Dipole moment (debye), $E$ : Energy level of HOMO or LUMO (eV), HOMO: Highest occupied molecular orbital, LUMO: Lowest unoccupied molecular orbital, $P$ : Population of each conformer at $298 \mathrm{~K}$.

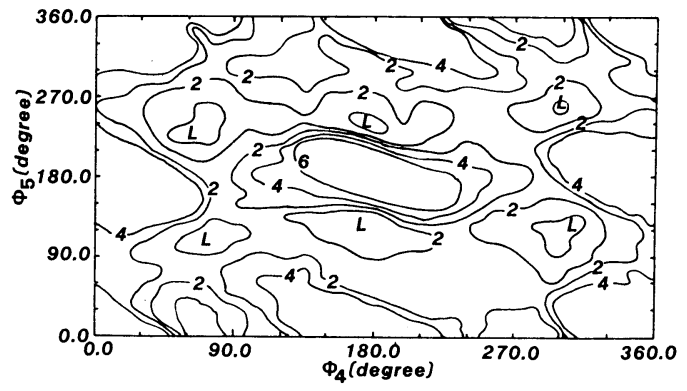

Fig. 4 Conformational analysis of (III) at $\left(\phi_{4}, \phi_{5}\right)$.

" $\mathrm{L}$ " indicates a lower energy state. $\phi_{4} ; \mathrm{C}_{2}-\mathrm{C}_{3}-$ $\mathrm{C}_{6}-\mathrm{C}_{7}$ and $\phi_{5} ; \mathrm{C}_{3}-\mathrm{C}_{6}-\mathrm{C}_{7}-\mathrm{C}_{8}$

small energy barrier.

\section{Steric Parameters}

The calculated four parameters, based on the global minimum energy conformer of each alcohol moiety, are summarized in Table 2 . Although the alcohol moieties of the potent pyrethroids tested show various chemical structures, the deviation in distance $d(7.09 \AA$ in average) is very small $( \pm 0.73 \AA)$, about half of the $\mathrm{C}=\mathrm{C}$ bond length. On the other hand, the calculated $\phi, \theta_{1}$ and $\theta_{2}$ are $60.0 \pm 12.5^{\circ}, 93.4 \pm$ $20.5^{\circ}$ and $59.0 \pm 2.7^{\circ}$, respectively, with the deviation for $\theta_{2}$, which may regulate the relative configuration of two unsaturated moieties in an
Table 2 Steric parameters for potent pyrethroids.

\begin{tabular}{rrrrr}
\hline \multirow{2}{*}{ Compound } & \multicolumn{5}{c}{ Steric parameters } \\
\cline { 2 - 5 } & \multicolumn{1}{c}{$\phi$} & \multicolumn{1}{c}{$\theta_{1}$} & \multicolumn{1}{c}{$\theta_{2}$} & $d$ \\
\hline$(\mathbf{I})$ & 35.7 & 74.6 & 56.8 & 7.01 \\
$(\mathbf{I I})$ & 60.6 & 74.4 & 57.2 & 6.27 \\
$(\mathbf{I I I})$ & 65.8 & 114.2 & 59.3 & 8.00 \\
$(\mathbf{I V})$ & 60.7 & 74.9 & - & 6.60 \\
$(\mathrm{~V})$ & 68.1 & 111.4 & - & 7.95 \\
$(\mathrm{VI})$ & 44.0 & 127.6 & - & $\left.(6.73)^{\mathrm{a}}\right)$ \\
$(\mathrm{VII})$ & 69.2 & 110.6 & 62.8 & 6.70
\end{tabular}

$\phi, \theta_{1}$ and $\theta_{2}$ (degrees) and $d(\AA)$.

- : Unable to be calculated.

a) Interatomic distance between $\mathrm{C}_{5}$ and $\mathrm{C}_{9}$.

extremity of the molecule, being remarkably small. The similar angle $\left(c a .50^{\circ}\right)$ has been reported by Plummer et al. ${ }^{16)}$ for a 2,2'-bridged biphenyl-3-ylmethanol derivative possessing a high insecticidal activity. Since the deviations in $\phi$ and $\theta_{1}$ are large, these parameters are likely to adjust $d$ and $\theta_{2}$ to an appropriate value. These results strongly suggest that the optimal molecular shape of an alcohol moiety determined by $d$ and $\theta_{2}$ exists and that it is requisite for effective binding of a molecule at the respective receptor site. 
Table 3 The RMS and ESC values in superimposition between (I) and other alcohol moieties (II)-(VII).

\begin{tabular}{|c|c|c|c|c|c|c|c|c|c|c|c|c|c|c|c|c|c|c|c|}
\hline \multirow[b]{2}{*}{ (I) } & \multicolumn{17}{|c|}{ Compared atoms in superimposition } & \multirow{2}{*}{$\begin{array}{c}\mathrm{RMS} \\
(\AA)\end{array}$} & \multirow{2}{*}{ ESC } \\
\hline & $\mathrm{C}_{1}$ & $\mathrm{C}_{2}$ & $\mathrm{C}_{3}$ & $\mathrm{C}_{4}$ & $\mathrm{C}_{5}$ & $\mathrm{O}_{6}$ & $\mathrm{C}_{7}$ & $\mathrm{C}_{8}$ & $\mathrm{C}_{9}$ & $\mathrm{C}_{10}$ & $\mathrm{O}_{12}$ & $\mathrm{C}_{13}$ & $\mathrm{O}_{14}$ & $\mathrm{C}_{15}$ & $\mathrm{H}_{8}$ & $\mathrm{H}_{9}$ & $\mathrm{C}_{1}-\underline{\mathrm{C}} \mathrm{H}_{3}$ & & \\
\hline (II) & $\mathrm{C}_{1}$ & $\mathrm{C}_{2}$ & $\mathrm{C}_{3}$ & $\mathrm{C}_{4}$ & $\mathrm{C}_{5}$ & $\mathrm{O}_{6}$ & $\mathrm{C}_{7}$ & $\mathrm{C}_{8}$ & $\mathrm{C}_{9}$ & & $\mathrm{O}_{10}$ & $\mathrm{C}_{11}$ & $\mathrm{O}_{12}$ & $\mathrm{C}_{13}$ & & & $\mathrm{C}_{1}-\underline{\mathrm{C}} \mathrm{H}_{3}$ & 0.236 & 0.87 \\
\hline (III) & $\mathrm{C}_{2}$ & $\mathrm{C}_{1}$ & $\mathrm{C}_{5}$ & $\mathrm{O}_{4}$ & $\mathrm{C}_{3}$ & & $\mathrm{C}_{6}$ & $\mathrm{C}_{7}$ & $\mathrm{C}_{8}$ & $\mathrm{H}_{8}$ & & & & $\mathrm{C}_{17}$ & $\mathrm{C}_{12}$ & $\mathrm{C}_{9}$ & $\mathrm{H}_{2}$ & 0.598 & 0.17 \\
\hline (IV) & $\mathrm{C}_{1}$ & $\mathrm{C}_{2}$ & $\mathrm{C}_{3}$ & $\mathrm{C}_{4}$ & $\mathrm{C}_{5}$ & $\mathrm{O}_{6}$ & $\mathrm{C}_{7}$ & $\mathrm{C}_{8}$ & & & $\mathrm{O}_{10}$ & $\mathrm{C}_{11}$ & $\mathrm{O}_{12}$ & $\mathrm{C}_{13}$ & & & $\mathrm{C}_{1}-\underline{\mathrm{CH}_{3}}$ & 0.113 & 0.19 \\
\hline$(\mathbf{V})$ & $\mathrm{O}_{2}$ & $\mathrm{C}_{1}$ & $\mathrm{C}_{5}$ & $\mathrm{C}_{4}$ & $\mathrm{C}_{3}$ & $\mathrm{H}_{4}$ & $\mathrm{C}_{6}$ & $\mathrm{C}_{7}$ & & & & & & $\mathrm{C}_{13}$ & & & & 0.434 & 0.25 \\
\hline$(\mathbf{V I})$ & $\mathrm{C}_{2}$ & $\mathrm{C}_{1}$ & & $\mathrm{H}_{3}$ & $\mathrm{C}_{3}$ & & $\mathrm{C}_{4}$ & $\mathrm{C}_{5}$ & & & & & & $\mathrm{C}_{11}$ & & & $\mathrm{C}_{2}-\underline{\mathrm{CH}_{3}}$ & 0.453 & 0.19 \\
\hline (VII) & $\mathrm{C}_{2}$ & $\mathrm{C}_{1}$ & & $\mathrm{C}_{4}$ & $\mathrm{C}_{3}$ & & $\mathrm{O}_{7}$ & $\mathrm{C}_{8}$ & $\mathrm{C}_{9}$ & $\mathrm{H}_{9}$ & & & & $\mathrm{C}_{18}$ & $\mathrm{C}_{13}$ & & $\mathrm{H}_{2}$ & 0.611 & 0.11 \\
\hline
\end{tabular}

The atoms in a column are utilized for superimposition and calculation of the RMS value.

$\mathrm{H}_{i}$ means the hydrogen atom attached to the $\mathrm{C}_{i}$ atom.

\section{Similarity in Molecular Shape}

The RMS values varying from 0.1 to 0.6 seem to be determined mainly by the degree of matching at the 2,4-pentadienyl moiety of (I). The results are summarized in Table 3 . Some of the superimpositions are shown by using skeleton models in Fig. 5, which shows that the furyl, phenyl and alkenyl moieties are well superimposed on the cyclopentenone ring of (I). The 1,2-unsaturated bond of phenyl groups in (III) and (VII) and the ethyl group of (VI) are located in the similar position occupied by the 2,4pentadienyl moiety of (I). In spite of the structural difference in a functional group at the molecular end, good molecular matching in planes (b) and (c) was also observed in other alcohol moieties. Matsuo et al. ${ }^{17)}$ have reported that empenthrin ((-)-S-2852) possessing (VI) as an alcohol moiety shows a high activity, which corresponds to the matching in molecular shape between (I) and (VI). These results strongly suggest that the optimal position of a molecular end, which is determined by $d$ and $\theta_{2}$, is requisite for an activity, but that the presence of an unsaturated $\mathrm{C}=\mathrm{C}$ bond is of minor importance.

The $[S]$ configuration in the alcohol moieties of (I), (II) and (IV) is known to be requisite for a higher activity. ${ }^{18,19)}$ In order to estimate the effect of an optical isomerism on activity, the molecular shapes of (II) and the corresponding $[R]$ enantiomer were compared under the condition that the acyl and allyl moieties of each molecule occupied the similar positions. Figure 6 shows that the cyclopentenone ring of each enantiomer is located near the similar plane, but that the methyl group attached to the $C_{1}$ atom of each enantiomer is orientated to the opposite direction. This difference in molecular shape may result in the poor activity of the $[R]$

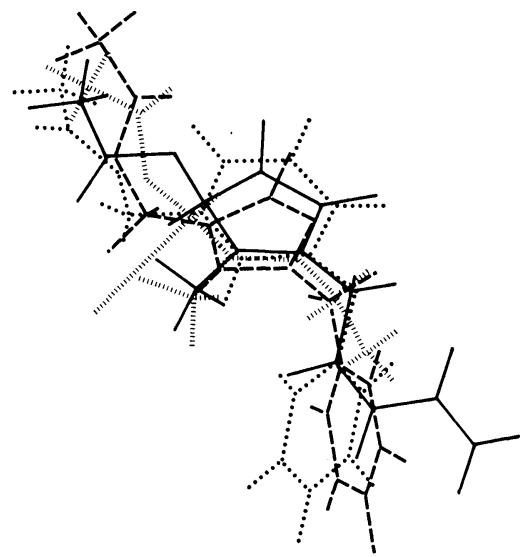

Fig. 5 Superimpositions of (III), (VI) and (VII) on (I).

$(\mathbf{I}):-,(\mathbf{I I I}):---,(\mathbf{V I}):$ :m!n! and $(\mathbf{V I I}): \cdots \cdots$

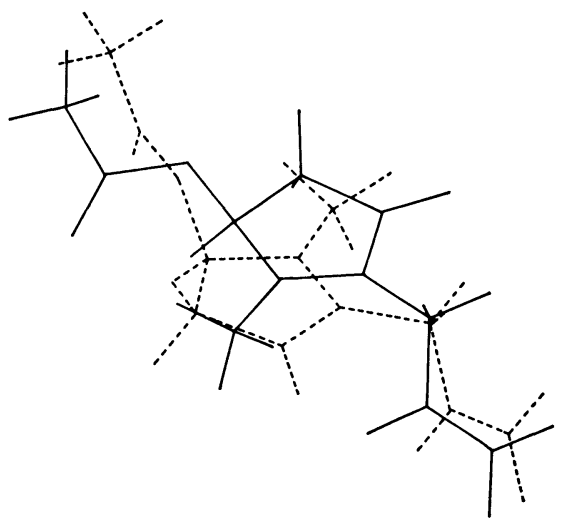

Fig. 6 Superimposition of the $[R]$ enantiomer of (II) (-- ) onto the corresponding [S] enantiomer (-). 
Table 4 Energy levels and distributions of HOMO and LUMO for the global minimum energy conformers of $(\mathbf{I})-(\mathbf{V I I})$.

\begin{tabular}{|c|c|c|}
\hline \multirow{2}{*}{ Compound } & \multicolumn{2}{|r|}{ HOMO } \\
\hline & Energy level (eV) & Distribution $(\%)$ \\
\hline$(\mathbf{I})^{\mathrm{a})}$ & -9.109 & $\mathrm{C}_{8}(28.9), \mathrm{C}_{9}(21.4), \mathrm{C}_{10}(13.6), \mathrm{C}_{11}(26.2)$ \\
\hline (II) & -9.906 & $\mathrm{C}_{1}(27.5), \mathrm{C}_{5}(31.7)$ \\
\hline (III) & -9.058 & $\mathrm{C}_{1}(13.3), \mathrm{C}_{2}(14.2), \mathrm{C}_{3}(30.4), \mathrm{C}_{5}(29.4)$ \\
\hline$(\mathbf{I V})$ & -10.058 & $\mathrm{C}_{1}(29.4), \mathrm{C}_{5}(37.8)$ \\
\hline$(\mathbf{V})$ & -9.237 & $C_{1}(13.0), C_{3}(31.6), C_{4}(15.6), C_{5}(32.8)$ \\
\hline$(\mathbf{V I})$ & -9.634 & $\mathrm{C}_{2}(37.3), \mathrm{C}_{3}(36.5)$ \\
\hline \multirow[t]{2}{*}{$(\mathbf{V I I})$} & -8.971 & $\mathrm{C}_{1}(16.3), \mathrm{C}_{3}(11.8), \mathrm{C}_{6}(13.9), \mathrm{O}_{7}(15.0)$ \\
\hline & & $\mathrm{C}_{8}(10.1), \mathrm{C}_{11}(12.1)$ \\
\hline \multirow{2}{*}{ Compound } & \multicolumn{2}{|r|}{ LUMO } \\
\hline & Energy level (eV) & Distribution (\%) \\
\hline$(\mathbf{I})^{\mathrm{a})}$ & -0.258 & $\mathrm{C}_{1}(30.0), \mathrm{C}_{5}(36.0)$ \\
\hline (II) & -0.233 & $\mathrm{C}_{1}(31.6), \mathrm{C}_{4}(17.6), \mathrm{C}_{5}(21.8), \mathrm{O}_{6}(13.1)$ \\
\hline (III) & +0.374 & $\mathrm{C}_{7}(29.1), \mathrm{C}_{10}(27.0), \mathrm{C}_{12}(10.7)$ \\
\hline$(\mathbf{I V})$ & -0.296 & $\mathrm{C}_{1}(37.7), \mathrm{C}_{4}(17.0), \mathrm{C}_{5}(21.6), \mathrm{O}_{6}(12.7)$ \\
\hline$(\mathbf{V})$ & +0.403 & $\mathrm{C}_{1}(12.5), \mathrm{C}_{3}(28.0), \mathrm{C}_{4}(11.4), \mathrm{C}_{5}(26.9)$ \\
\hline (VI) & +0.799 & $\mathrm{C}_{2}(30.7), \mathrm{C}_{3}(38.4)$ \\
\hline \multirow[t]{2}{*}{ (VII) } & +0.117 & $\mathrm{C}_{1}(17.0), \mathrm{C}_{3}(13.0), \mathrm{C}_{4}(19.4), \mathrm{C}_{6}(14.9)$ \\
\hline & & $\mathrm{C}_{8}(10.7)$ \\
\hline
\end{tabular}

The atoms with an electron density of above $10 \%$ are listed.

a) Conformer 1 .

enantiomer.

\section{Electronic Properties}

The energy levels and distributions of HOMO and LUMO are summarized in Table 4. Since the dipole moment of each alcohol moiety estimated by AM1 was found in the range of 1.8 to 3.2 debye, it is difficult to correlate the dipole moment of a molecule with its activity. Both HOMO and LUMO are localized in plane (b) in (II), (IV), (V) and (VI), while those of (VII) distribute both at the 3-phenoxy and benzyl moieties, and thus their localization at plane (b) or (c) is reduced. Furthermore, HOMO and LUMO of (I) and (III) are separately localized in different regions such as planes (b) and (c). The ESC values listed in Table 3 show the low electrostatic correlation $(\mathrm{ESC}=0.11-0.25)$, except compound (II) whose chemical structure is close to that of $(\mathbf{I})$. The results indicate that the electronic properties of an alcohol moiety are of minor importance for the insecticidal activity of pyrethroids.

\section{CONCLUSION}

Molecular calculations and computer graphics demonstrated that the appropriate configuration of an alcohol moiety is requisite for potent pyrethroids, and that electronic properties, such as electrostatic potential and distributions of frontier molecular orbitals, are of minor importance for higher insecticidal activity.

\section{ACKNOWLEDGMENTS}

The authors are indebted to Dr. C. Takayama of Sumitomo Chemical Co., Ltd. for useful discussions.

\section{REFERENCES}

1) M. Elliott \& N. F. Janes: Chem. Soc. Rev. 7, 473 (1978)

2) M. Elliott \& N. F. Janes: "Synthetic Pyrethroids," ed. by M. Elliott, ACS Symposium Series 42, Chapter 2, American Chemical Society, Washington D. C., p. 29, 1977

3) A. J. Hopfinger, D. Malhotra, R. D. Battershell \& A. W. Ho: J. Pesticide Sci. 9, 631 (1982)

4) C. Tosi, L. Barino, G. Castellani \& R. Scordamaglia: J. Mol. Struct. 87, 315 (1985) 
5) M. Elliott: "Recent Advances in the Chemistry of Insect Control," ed. by N. F. Janes, Royal Society of Chemistry, London, p. 73, 1985

6) K. Nishimura, T. Kitahaba, N. Okajima \& T. Fujita: Pestic. Biochem. Physiol. 23, 314 (1985)

7) D. W. Gammon, M. A. Brown \& J. E. Casida: Pestic. Biochem. Physiol. 15, 181 (1981)

8) L. J. Lawrence \& J. E. Casida: Pestic. Biochem. Physiol. 18, 9 (1982)

9) M. Yoshida, C. Takayama, S. Morooka \& A. Yokota: 7th Int. Conf. Comput. Chem. Res. Educ., No. 32, 1985

10) M. J. S. Dewar, E. G. Zoebisch, E. F. Hearly \& J. J. P. Stewart: J. Am. Chem. Soc. 107, 3902 (1985); Quantum Chem. Program Exch., No. $523(1985)$

11) S. Diner, J. P. Marlieu \& P. Claverie: Theoret. Chim. Acta (Berl.) 13, 1 (1969); Quantum Chem. Program Esch. No. 220 (1971)

12) W. Kabsch: Acta Cryst. A32, 922 (1976)

13) T. Ohsumi, C. Takayama, T. Motoki, T. Yano, M. Hirano \& N. Itaya: J. Pesticide Sci. 12, 659 (1987)

14) A. Nakayama \& G. Richards: Quant. Struct.Act. Relat. 6, 153 (1987)

15) Y. Kurita \& C. Takayama: to be published

16) E. L. Plummer, R. P. Seiders, D. E. Seelye \&
R. R. Stewart: Pestic. Sci. 15, 509 (1984)

17) N. Matsuo, T. Yano \& H. Yoshioka: Agric. Biol. Chem. 45, 1915 (1981)

18) W. A. Gersdorff \& P. G. Piquett: J. Econ. Entomol. 51, 181 (1958)

19) T. Matsuo, T. Nishioka, M. Hirano, Y. Susuki, K. Tsushima, N. Itaya \& H. Yoshioka: Pestic. Sci. 11, 202 (1980)

要 約

\section{ピレスロイドアルコール部分の分子形状の類似性}

片木敏行, 栗田靖之

天然ピレスリン-I，ならびに神経生理学的にタイプI と呼ば れる合成ピレスロイドのアルコール部分の安定構造を分子軌道 法計算 (PCILO, AM1) による立体配座解析, 構造最適化によ り推定した. 得られた最安定コンフォーマーを用い，これらの 立体形状について ACACS システムにより調べた結果, よい類 似性が認められた．また，ピレスリンーIのシクロペンテノン環 と分子末端の 2,4 -ペンタジェニル基を含む平面のなす角度 $\left(59^{\circ}\right)$ が，他の高い殺虫活性を有するピレスロイドの対応する 部分でも認められ，分子の形状が殺虫活性発現に寄与している ことが推定された. 一方, 電子分布や分子表面における静電ボ テンシャルには類似性が認められず, 電子的な性質が活性発現 においては 2 次的なものであると推定された. 